\title{
EWOLUCJA CZY REWOLUCJA? PRZEMIANY RODZINY NA ZIEMIACH POLSKICH W PIERWSZEJ POŁOWIE XX WIEKU. WYBRANE ASPEKTY
}

\section{Katarzyna Sierakowska}

(10) http://orcid.org/0000-0001-7998-7124

Instytut Historii im. Tadeusza Manteuffla PAN w Warszawie

\author{
ABSTRACT \\ EVOLUTION OR REVOLUTION? TRANSFORMATIONS OF FAMILY \\ IN THE POLISH LANDS IN THE FIRST HALF OF THE TWENTIETH \\ CENTURY: SELECTED ASPECTS
}

The text focuses on select issues related to the transformation of the family in the first half of the twentieth century, such as: changes regarding marital choices and relationships between spouses, changes in the scope of parental roles and the processes of individualization and individual autonomy in the family. It tries to answer the questions about the dynamics of these processes in different social milieus and to indicate factors that accelerated and delayed them. The analysis of the sources and literature concerning family lives does not allow for an unambiguous assessment of the rapidity and range of changes taking place in families. Nevertheless, it exposes the diversity of models existing in family life and shows that it depends on such elements as social environment, gender, idiosyncratic features of the individual, to the same extent as it does on the rate of change.

Keywords: social history of the 20th century, family history of the 20th century.

Słowa kluczowe: historia społeczna XX wieku, historia rodziny XX wieku.

Badania nad rodziną mają swoją tradycję w polskiej historiografii. Jednak poszczególne okresy nie są tu reprezentowane w tym samym stopniu. Na prawach źródeł funkcjonują dziś broszury zarówno z przełomu wieków XIX i XX, jak i liczne opracowania i ankiety przygotowywane przede wszystkim przez Instytut Gospodarstwa Społecznego z okresu dwudziestolecia międzywojennego. Dla pierwszej połowy XX wieku ukazały się opracowania monograficzne dotyczące rodziny 


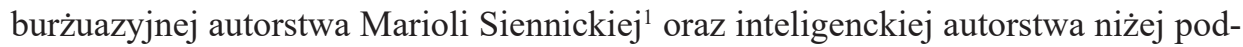
pisanej $^{2}$. Funkcjonowanie robotniczych rodzin warszawskich omawia w swojej książce i niektórych artykułach Anna Żarnowska³ . Książka Marty Sikorskiej-Kowalskiej z 2001 roku została poświęcona funkcjonowaniu kobiet w rodzinach burżuazji łódzkiej z naciskiem na życie Anny Geyer ${ }^{4}$ O macierzyństwie traktują prace Anety Bołdyrew oraz Małgorzaty Stawiak-Ososińskiej, choć ta druga dotyczy raczej pierwszej połowy XIX wieku i z tego powodu może stanowić jedynie punkt wyjścia dla poniższych refleksji. Ważne informacje na temat funkcjonowania rodzin chłopskich zawiera praca Włodzimierza Mędrzeckiego poświęcona socjalizacji młodzieży, ale poza tym zagadnieniem autor sporo miejsca przeznaczył na opis relacji rodzinnych, w tym również doborów małżeńskich ${ }^{5}$. Podobnie niektóre artykuły zawarte w opracowaniach zbiorowych, takich jak Rodzina, prywatność, intymność. Dzieje rodziny polskiej w kontekście europejskim oraz w serii Kobieta $i . . .$, wzbogaciły naszą refleksję o rodzinach na ziemiach polskich ${ }^{6}$. Omawiając stan badań, warto też przywołać nieco starsze opracowania - między innymi Stefanii Kowalskiej-Glikman (o drobnomieszczaństwie), niektóre prace Janiny Leskiewiczowej, Janiny Żurawickiej czy Janusza Żarnowskiego ${ }^{7}$. Wiedzę naszą wzbogacają też opracowania etnograficzne poświęcone między innymi życiu robotników w Łodzi czy Żyrardowie ${ }^{8}$. Informacje ilościowe przynoszą zarówno dane ze spisów różnego rodzaju, w tym dwóch z okresu dwudziestolecia międzywojennego - z 1921 i 1931 roku. Dysponujemy też opracowaniami z zakresu demografii historycznej: Lidii Zyblikiewicz, Konrada Wnęka i Bartosza Ogórka9 ${ }^{9}$ W ostatnim dziesięcioleciu można jednak zauważyć

${ }^{1}$ M. Siennicka, Rodzina burżuazji warszawskiej i jej obyczaj: druga połowa XIX i początek XX wieku, Warszawa 1998.

${ }^{2}$ K. Si riakowska, Rodzice, dzieci, dziadkowie... Wielkomiejska rodzina inteligencka $w$ Polsce w latach 1918-1939, Warszawa 2002.

${ }^{3}$ A. Żarnow ska, Robotnicy Warszawy na przelomie XIX i XX wieku, Warszawa 1995.

${ }^{4}$ M. Si korska-Kow alska, Wizerunek kobiety tódzkiej przełomu XIX i XX wieku, Łódź 2001.

${ }_{5}^{5}$ W. Mędrzeck i, Młodzież wiejska na ziemiach Polski centralnej 1864-1939: procesy socjalizacji, Warszawa 2002.

${ }^{6}$ Rodzina - prywatność - intymność: dzieje rodziny polskiej w kontekście europejskim: zbiór studiów, red. D. Kałwa, A. Wal aszek, A. Żarnowska, Warszawa 2005.

7 S. Kowalska-Glikman, Drobnomieszczaństwo w XIX-wiecznej Warszawie, Warszawa 1987; J. Leskiewiczowa, Warszawa i jej inteligencja po powstaniu styczniowym 1864-1870, Warszawa 1961; Społeczeństwo polskie XVIII i XIX wieku, t. 9. Studia o rodzinie, red. J. Le ski e wiczowa, Warszawa 1991; J. Żurawicka, Inteligencja warszawska w końcu XIX wieku, Warszawa 1978; J. Żarnowski, O inteligencji polskiej lat międzywojennych, Warszawa 1965; idem, Społeczeństwo Drugiej Rzeczypospolitej: 1918-1939, Warszawa 1973.

${ }^{8}$ Np. B. Kopczyńska-Jaw orska, Lódź i inne miasta, Łódź 1999; Wybrane problemy etnologii miasta, red. nauk. B. Ko p c zyń s k a - Ja w or s k a, Łódź 1993; A. S t a w ar z, Życie codzienne w dawnym Żyrardowie 1830-1880, Żyrardów 1983; Materiaty do etnografii miasta, cz. 1, red. A. Stawarz, Żyrardów 1992; Tradycyjna kultura robotnicza Żyrardowa, red. A. Woźniak, Warszawa 1982.

${ }^{9}$ L. Zyblikiewicz, Kobieta $w$ Krakowie $w 1880 \mathrm{r} . w$ świetle ankiet powszechnego spisu ludności. Studium demograficzne, Kraków 1999; eadem, Dziecko w rodzinie krakowskiej w drugiej połowie XIX wieku: studium demograficzne, „Zeszyty Naukowe Uniwersytetu Jagiellońskiego. Prace Historyczne" 2008, z. 135, s. 129-147; K. Wnę k, Przemiany demograficzne we Lwowie w latach 1829-1938, „Zeszyty Naukowe Uniwersytetu Jagiellońskiego. Prace Historyczne” 2008, z. 135, s. 113 
pewien odwrót od tematyki rodzinnej. Nie tu jest jednak miejsce, aby zastanawiać się nad przyczynami tego stanu rzeczy - pozostanę więc przy tej ogólnej konstatacji.

Jak wynika nawet $\mathrm{z}$ tego, siłą rzeczy pobieżnego i niepełnego przeglądu, problematyka związana z rodziną jest bardzo szeroka. Ze względu na to, że obejmuje tak wiele sfer, jak m.in.: kwestię ról rodzinnych, relacji w rodzinie, jej postrzegania w społeczeństwie oraz wpływu na jednostki i grupy, życia codziennego, kultury pracy i czasu wolnego, pojawia się w bardzo wielu opracowaniach, wciąż natomiast mało jest na gruncie historycznym opracowań syntetycznych, choć i tak omawiany tu okres nie należy do najbardziej upośledzonych. Wydaje się jednak, że wciąż jeszcze pozostaje do postawienia wiele pytań badawczych.

W przedstawianym tekście spróbuję odpowiedzieć na zawarte w tytule pytanie o naturę zmian zachodzących w rodzinie. Umiejscowienie refleksji pomiędzy opozycją ewolucja - rewolucja jest tak naprawdę przede wszystkim pytaniem o szybkość zmian i naturę modernizacji. Determinuje też w dużym stopniu przedmiot rozważań. Rodzinie bowiem można przyglądać się, biorąc pod uwagę różne punkty odniesienia - począwszy od geograficznych, skończywszy na psychologicznych. Dla mnie istotne jest przede wszystkim zbadanie sposobu definiowania ról rodzinnych i warunków życia codziennego. Namysłu wymaga też sama definicja rodziny, jak bowiem sugerują badacze, wyznacza ona pole refleksji, a w ostatnim czasie sama rodzina ulega głębokim i bardzo istotnym zmianom - można tu jako przykład przytoczyć choćby znaczący wzrost rodzin rekonstruowanych czy patchworkowych (zresztą akurat tą kwestią też należałoby się zająć dla okresu przed II wojną światową - bo choć nie używano takiego terminu, to rodziny takie istniały także wtedy) oraz pojedynczych gospodarstw domowych. Przyjmuję, że zgodnie z wymową źródeł rodzinę w badanym okresie definiowano w sposób tradycyjny jako małżonków i ich potomstwo. Czasem włączano też do niej inne osoby - dziadków, dalszych krewnych czy nawet sublokatorów ${ }^{10}$.

Rodziny, tradycyjnie rozumiane, można podzielić zarówno według narodowości, jak i według przynależności do konkretnej grupy społecznej. Jeśli chodzi o pierwsze wymienione kryterium, to główna oś przebiega na ziemiach polskich, moim zdaniem, wzdłuż linii chrześcijańskie i żydowskie, a więc zgodnie z kryterium nie tyle narodowościowym, co religijnym. O rodzinach żydowskich będę wspominać w swoich rozważaniach tylko incydentalnie. Jako wsparcie można się odwołać do niektórych

127; B. Ogórek, Niezatarte piętno? Wplyw I wojny światowej na ludność miasta Krakowa, Kraków 2018; idem, »Należy przestać spluwać dzieci na prawo i lewo«. Transformacja płodności w populacji Drugiej Rzeczypospolitej [w:] Społeczeństwo międzywojenne nowe spojrzenie, red. W. Mędrzecki, J. Żarnow ski, Metamorfozy Społeczne, t. 10, Warszawa 2015, s. 81-111.

${ }^{10} \mathrm{Na}$ przykład w rodzinach robotników warszawskich dochodziło zdaniem Anny Żarnowskiej do kształtowania się takiego modelu pod wpływem wielkomiejskiego stylu życia; por. A. Żarnowska, Modele rodziny i pozycja $w$ niej kobiety $w$ uprzemystawiającym się mieście na przełomie XIX $i$ XX wieku. Tradycja i modernizacja [w:] A. Żarnowska, Kobieta i rodzina w przestrzeni wielkomiejskiej na ziemiach polskich $w X I X i X X$ wieku, red. A. Janiak-Jasińska, K. Sierakowska, A. Szwarc, Warszawa 2013, s. 24. 
badań Anny Landau-Czajki, Moniki Rüthers, Aliny Całej czy Joanny Lisek ${ }^{11}$. Co do podziału według przynależności do grup społecznych, można wyróżnić rodziny arystokratyczne, ziemiańskie, drobnej szlachty, chłopskie oraz miejskie: inteligenckie, burżuazyjne, drobnomieszczańskie i robotnicze. W każdej z tych grup dostrzegamy też wewnętrzne zróżnicowanie. To, że to zróżnicowanie odbija się w sposobie funkcjonowania rodzin, jest oczywiste, jednak warto byłoby zastanowić się, czy można tu wskazać warstwy, czy grupy wzorotwórcze, do których inne aspirują, czy też raczej każda $\mathrm{z}$ nich rozwija się $\mathrm{w}$ swoim własnym tempie i zgodnie $\mathrm{z}$ tworzonymi lub też modelowanymi przez siebie wzorami. Jeżeli podzielamy przekonanie, że istnieje jakiś wzorzec, do którego dążymy, to warto by go wskazać. Dotychczasowe badania zdają się potwierdzać tezę, że zmiany zachodziły w badanym czasie raczej powoli niż gwałtownie, że środowiska miejskie zarówno je generowały, jak i szybciej im ulegały. Doskonałym przykładem może być dyskusja, która odbywała się na łamach prasy kobiecej w dwudziestoleciu międzywojennym. Wskazuje ona, że dla wielu kobiet okres międzywojenny stanowił czas swego rodzaju przełomu. Z jednej strony coraz bardziej zaawansowane procesy emancypacji kobiet wyrażające się w postępującej samodzielności: finansowej, związanej z podejmowaniem istotnych życiowych decyzji, w tym także dotyczących zamążpójścia, oraz wzrost swobody obyczajowej pchały kobiety w stronę coraz większej niezależności, stawiały je przed koniecznością wyboru drogi życiowej i sposobu samorealizacji, prowadziły do kwestionowania roli żony i matki jako jedynego źródła spełnienia i satysfakcji. Z drugiej jednak strony ciążenie tradycji wyrażanej przede wszystkim przez zstępnych, wzory podtrzymywane przez religie, a także (zagadnienie to wymaga jednak dalszych badań) polityka państwa wymagały od kobiet realizacji tradycyjnych ról, poświęcenia się domowi i dzieciom.

Wydaje mi się, że odpowiedź na pytanie „ewolucja czy rewolucja?” pozwala popatrzeć na tę różnorodność rodzin w sposób syntetyczny niejako z lotu ptaka. Skupię się na tych obszarach i środowiskach, w których zachodziły w badanym okresie zmiany. Niewątpliwie wiązały się one przede wszystkim z miastem, z rozwojem medycyny i higieny oraz postępującymi procesami autonomizacji i indywidualizacji jednostki.

Zakreślenie pola obserwacji w przedziale pierwszej połowy XX wieku, choć nie wydaje się szczególnie kontrowersyjne, wymaga jednak pewnych wyjaśnień. Określenie „pierwsza połowa XX wieku” rozumiem umownie. Dla przemian społecznych, w tym dla przemian zachodzących w rodzinie, rok 1900 nie stanowi żadnej szczególnej cezury czasowej. W zasadzie przemiany rozpoczęły się już kilka dziesięcioleci wcześniej - będąc wynikiem uwłaszczenia, rozpoczętej i postępującej emancypacji

${ }^{11} \mathrm{Na}$ ten temat więcej informacji zawierają m.in. prace: A. Landau-Czajka, ,Syn będzie Lech". Asymilacja Żydów w Polsce międzywojennej, Warszawa 2006; M. Rüthers, Tewjes Töchter. Lebensentwürfe ostjüdischer Frauen im 19.Jahrhundert, Köln 1996; A. Cała, Ostatnie pokolenie. Autobiografie polskiej młodzieży żydowskiej okresu międzywojennego ze zbiorów YIVO Institute for Jewish Research w Nowym Jorku, Warszawa 2003; Grzeszne wiersze o matce. Pożegnanie z Jidysze Mame? [w:] Pożegnanie z Matką Polką? Dyskursy, praktyki i prezentacje macierzyństwa we współczesnej Polsce, red. R.E. Hryciuk, E. Korolczuk, Warszawa 2012, s. 165-186 [współautorka: A. Gaj ew sk a]. 
kobiet, procesów urbanizacji i industrializacji. W końcu nie bez znaczenia będą też symboliczne daty - rewolucji 1905 roku, która na terenie Królestwa Polskiego doprowadziła do rozpoczęcia wielu debat związanych z modernizacją społeczną, w tym między innymi debaty o podwójnej moralności czy zakresie równouprawnienia kobiet. W końcu wiek XX został przez Ellen Key obwołany wiekiem dziecka, co niewątpliwie wpłynęło na dynamikę debaty społecznej dotyczącej roli i miejsca dzieci w rodzinie i społeczeństwie. Cezura zamykająca wydaje się nieco bardziej precyzyjna - jest nią wybuch II wojny światowej.

Prowadząc rozważania dotyczące rodziny, nie można pominąc zróżnicowania między zaborami, bo choć wydaje się, że przemiany społeczne postępowały na wszystkich ziemiach polskich w podobnym kierunku, jednak ich tempo na pewno nie było takie samo. Redaktorzy serii Kobieta $i . .$. w 2004 roku pisali:

Tak czy inaczej z pewnością można przyjąć, że w Polsce nie tylko w wieku XIX, ale co najmniej do końca dwudziestolecia międzywojennego, dążenie do małżeństwa uznawane było za cel życiowy kobiety, determinujący jej szanse życiowe i społeczne role, a na wielu szczeblach drabiny społecznej odgrywało ono także istotną rolę w karierze i zdobywaniu stabilnej pozycji społecznej mężczyzny ${ }^{12}$.

\section{MAŁŻEŃSTWO, ALE JAKIE?}

Trudno się z nimi nie zgodzić, jednak trzeba zwrócić uwagę na fakt, że coraz częściej w tym dominującym sposobie postrzegania małżeństwa pojawiały się wyłomy. Widać je już w propagowanych wzorach wychowania, zwłaszcza dziewcząt. Zastanawiano się, i to coraz powszechniej, czy małżeństwo jest rzeczywiście jedynym celem życiowym, do którego warto dążyć, a przede wszystkim jakie czynniki powinny decydować o wyborze współmałżonka ${ }^{13}$. I coraz częściej dochodzono do wniosku, że małżeństwo z różnych powodów nie powinno być celem jedynym, że sytuacja ekonomiczno-społeczna zmusza do przygotowywania sobie alternatyw. Odbiorcami tego postulatu były przede wszystkim kobiety, które choć w badanym okresie nierzadko podejmowały pracą zarobkową, uznawały ją - w zasadzie we wszystkich środowiskach społecznych - za konieczność, a nie przywilej. Odmienne zdania słychać było rzadko. Werbalizowały je np. emancypantki ze Związku Równouprawnienia Kobiet Polskich czy Cecylia Plater-Zyberkówna. Nawet one jednak twierdziły, że jeśli kobieta zakłada rodzinę, to jej powinna poświęcić wszystkie swe siły. Trudno jednoznacznie wskazać wpływ Wielkiej Wojny na zmianę tego przekonania,

${ }^{12}$ A. Żarnowska, A. Szwarc, Przedmowa [w:] Kobieta i matżeństwo. Spoleczno-kulturowe aspekty seksualności. Wiek XIX $i$ XX, zbiór studiów pod red. A. Żarnowskiej, A. S zwarca, t. VIII, Warszawa 2004, s. XIX.

${ }^{13}$ A. Landau-Czajka, Przygotowanie do matżeństwa wedlug wybranych poradników z XIX i XX wieku [w:] Kobieta i malzeństwo: spoteczno-kulturowe aspekty seksualności: wiek XIX i XX, red. A. Żarnowska, A. Szwarc, s. 13. 
choć bardzo prawdopodobne wydaje się, że luka demograficzna przez nią wywołana oraz pogorszenie ekonomicznych warunków życia wraz z postępującymi procesami emancypacyjnymi mogło mieć wpływ na przyśpieszenie zmiany paradygmatu wychowawczego zwłaszcza w przypadku dziewcząt. Dotyczyło to zarówno czynników determinujących czy skłaniających do małżeństwa, jak i definiowania cech przyszłych współmałżonków i określania relacji między nimi. I wojna światowa niewątpliwie przyśpieszyła wkroczenie znacznej grupy kobiet, głównie ze środowisk należących do tzw. warstwy oświeconej, na rynek pracy, podjęcia przez nie masowo kształcenia na szczeblu średnim i wyższym i rozbudzenia ich indywidualnych aspiracji. Uzyskanie samodzielności ekonomicznej niewątpliwie też przyczyniało się do zmiany relacji między płciami. Kobiety coraz częściej chciały i podejmowały samodzielne decyzje dotyczące swojego życia. Powtarzały niejako drogę pierwszych studentek, które opuszczając dom rodzinny i udając się na studia, uzyskiwały samodzielność i korzystały z niej - co między innymi odbijało się i w ich decyzjach matrymonialnych, przykład mogą stanowić Maria Dąbrowska czy Justyna Budzińska-Tylicka. Jak pokazują badania, coraz częściej czynnikiem decydującym o wstąpieniu w związek małżeński było uczucie łączące młodych, a przynajmniej ich wola do wspólnego marszu przez życie. Na łamach postępowej „Kosmetyki” już w 1908 roku pisano: „Czy istnieje coś bardziej nieetycznego, coś wstrętniejszego, jak ten handel żywym towarem, jak to łączenie ze sobą dozgonnym węzłem dwojga ludzi wzajem sobie najobojętniejszych na świecie?"'14. Nie znaczy to jednak, że w badanym okresie rodzice nie mieli nic do powiedzenia w sprawie małżeństw swoich dzieci. Wciąż jeszcze, zwłaszcza w tradycyjnych rodzinach chłopskich lub arystokratycznych, to do rodziców należał decydujący głos. W tych przypadkach wciąż uważano, że małżeństwo jest zawierane przede wszystkim $w$ interesie rodziny. Jako przykład niech posłuży cytat z Pamiętników chlopów. Kobieta z powiatu mazowieckiego wspominała swoje doświadczenia z okresu, gdy była jeszcze panną: „Ponieważ był to chłopak młody i podobaliśmy się sobie, nadmienił pewnego razu ojcu, że pragnąłby się ze mną ożenić, lecz dostał taką odprawę od ojca, że więcej się już nie pokazał, a mnie zapowiedział ojciec, żebym sobie żadnymi mieszczuchami głowy nie zawracała, bo jeżeli mnie wyda to tylko za gospodarza. Cóż było robić? Serce się zakrwawiło, lecz ojca wola była nieugięta”" I I dalej dodawała: „A ponieważ po większej części jest na wsi taki zwyczaj, że nigdy się dziewczyny o zgodę nie pytają, więc i w tym wypadku »obrabiali« interes tylko z ojcem”. Nieco inaczej małżeństwo przedstawiali mężczyźni z tego środowiska, postrzegani jako strona aktywna. Zwykle wybierali oni pannę, której rodzina żyła na podobnym poziomie materialnym co starający się o rękę. Wskazując na inne przyczyny, które skłaniały ich do wstępowania w związek małżeński, podkreślali współpracę i łatwiejsze życie we dwoje. Wynurzenia zawarte $\mathrm{w}$ pamiętnikach chłopskich z pozoru utwierdzają w przekonaniu o konserwatyzmie wsi, jednak gdy relacje poddać dokładniejszej analizie, możemy dostrzec rysy

${ }^{14}$ Kwestie drażliwe w oświetleniu etycznym, cz. VI: Kilka słów o wspótczesnej etyce małżeńskiej, „Kosmetyka” 1908, nr 17, s. 157.

${ }^{15}$ Pamiętniki chłopów, Warszawa 1935, Pamiętnik nr 3, żona gospodarza piętnastomorgowego w powiecie warszawskim, rocznik 1900, s. 34. 
w wydawałoby się jednoznacznie tradycyjnym obrazie. Cytowana gospodyni np. zdaje sobie sprawę, że w mieście bardziej liczono się ze zdaniem kobiet - tu w kwestii małżeństwa. Dostrzega też, że ważnym elementem związku jest uczucie. Można też zauważyć, że już nie dla wszystkich najważniejszy jest wyłącznie materialny aspekt relacji małżeńskiej. Jednak jak wynika z ustaleń Włodzimierza Mędrzeckiego, przez cały okres międzywojenny większość małżeństw (jeśli w ogóle je zawierano, wspomniany autor twierdzi, że znaczna grupa młodzieży wiejskiej obojga płci odwlekała decyzję o wstąpieniu w związek małżeński ze względu na brak zabezpieczenia materialnego) zawierano z rozsądku, tj. uwzględniając interesy rodziny, wolę rodziców ${ }^{16}$. W środowisku robotniczym, jak się wydaje, uczucie również rzadko stanowiło główne kryterium wyboru małżonka ${ }^{17}$. Kobiety zwracały na ogół uwagę na stabilność pracy przyszłego kandydata na męża i na to, aby nie nadużywał alkoholu, np. „Wyszłabym za mąż, gdyby się kto trafił nie pijak i nie bardzo biedny ${ }^{18 ”}$. Warto tu jednak podkreślić samodzielność młodych w podejmowaniu decyzji. Chociaż myślenie o przyszłym kandydacie na męża nie było pozbawione praktycyzmu i życiowego rozsądku, to jednak, jak choćby w przytoczonej wypowiedzi, decyzja o wyborze należała do młodych. Z kolei w środowisku arystokratycznym małżeństwo traktowano w XIX wieku przede wszystkim jako element polityki rodzinnej. Nierzadko uciekano się do przymusu, który jednak niekiedy wywoływał bunt ${ }^{19}$. Wydaje się, że w latach międzywojennych również i w tym środowisku nastąpiły zmiany. Autor wspomnień Michał Szymon Karski, który ożenił się w 1926 roku, tak pisał: „Jak zwykle w owych czasach małżeństwo, a raczej jego zamiar był przedmiotem rodzinnych rozważań z obu stron, rozpatrywanie pro i contra. Dla mnie te sprawy nie istniały. Dokonałem wyboru, nie pytając Ojca o zdanie"20. Wspomnienia Matyldy z Windisch-Graetzów Sapieżyny również wskazują, że jej dzieci decyzję o wstąpieniu w związek małżeński podejmowały, nie pytając rodziców o zdanie, a czasem i wbrew ich woli ${ }^{21}$. Te zapiski pamiętnikarskie wskazują także na zmianę, jaka dokonywała się w relacjach między rodzicami i dziećmi. Można z nich wyczytać, a inne źródła to potwierdzają, wzrost poczucia indywidualizmu i poszanowania autonomii jednostki. Taka postawa z pewnością wynikała z upowszechniania się przekonania o indywidualności dzieci nie tylko jako grupy, ale również jako jednostek, którym należy się szacunek. Podobnie rozwijające się w tym czasie prądy wychowawcze podkreślały konieczność

${ }^{16}$ W. Mędrzecki, op. cit., s. 136-137, 192.

${ }^{17}$ K. Si r rakow ska, Rodzina robotnicza w Królestwie Polskim w drugiej połowie XIX i pierwszej XX wieku. Ujęcie kulturowe [w:] Rodzina, gospodarstwo domowe i pokrewieństwo na ziemiach polskich w perspektywie historycznej - ciagłość czy zmiana?, red. C. Kuk1o, Warszawa 2012, s. 334.

18 A. Oderfeldó w na, Młodzież przedmieścia. Z badań ankietowych na Ochocie, Warszawa 1937, s. 153 .

${ }_{19}$ Więcej na temat XIX-wiecznych małżeństw arystokracji, ich rozpadów i skandali patrz: A. S z w a r c, Rygorystyczne normy i swobodne obyczaje. Malżeństwo i zwiazki pozamalżeńskie w opiniach ziemiańsko-arystokratycznej elity w połowie XIX wieku [w:] Kobieta i matżeństwo...., s. 89-101.

${ }^{20}$ M.S. Karski, Pamiętniki, oprac. nauk. i edycja J. Greloff, Warszawa 2017, s. 229.

${ }_{21}$ M. Sapieżyna z Windisch-Graetzów, My i nasze siedliska, Kraków 2003, s. 373, 381, 392-393. 
wykształcania w dziecku samodzielności, której wyrazem od najmłodszych lat miały być też samodzielne wybory. Ich granicę stanowiło w zasadzie tylko dobro innych ${ }^{22}$.

Nowe kryteria zawarcia związku małżeńskiego wraz ze wzrastającym poszanowaniem indywidualizmu i autonomii jednostki prowadziły w konsekwencji do rozszerzenia zadań rodziny. Posiadanie i wychowanie potomstwa czy pomnożenie rodzinnego majątku nie było już ani jedynym, ani najważniejszym celem związku małżeńskiego. Równie ważne było poczucie osobistej satysfakcji, zadowolenia i spełnienia męża i żony. W dwudziestoleciu międzywojennym pisano w poradniku, że „małżeństwo nie powinno być walką dwojga płci, dążących do zabicia indywidualności, lecz współżyciem ludzi, posiadających odrębne cechy fizyczne i duchowe"23.

\section{RODZICIELSTWO}

Jeżeli zatem małżeństwo miało być współżyciem dwóch autonomicznych jednostek, dobrowolnym i pozwalającym obojgu małżonkom na samorealizację, to zrozumiała wydaje się dyskusja i nad dalszym rozwojem rodziny. Wyszła ona z kilku poza wymienioną przesłanek i dotyczyła w latach przed I wojną światową niemal wyłącznie miejskich środowisk oświeconych. Jedną z przesłanek była kwestia podwójnej moralności i chorób wenerycznych. Nie miejsce tu, żeby ten problem dokładniej omawiać, chcę jedynie podkreślić, że przy tej okazji okazało się, iż jedną z przyczyn takiego stanu rzeczy były pruderia społeczeństwa i opór przed przekazywaniem wiedzy o prokreacji i fizjologii płci. Istnieją świadectwa, choć nieliczne, z których wynika, że kobiety wychodzące za mąż nie bardzo wiedziały, skąd się biorą dzieci. Z kolei badania prowadzone wśród młodzieży męskiej na przełomie wieków wskazywały jednoznacznie, że jej inicjacja seksualna najczęściej dokonuje się w domach publicznych lub w przypadkowych kontaktach ze służbą domową. Historyczka Jolanta Sikorska-Kulesza pisała:

Śmiało można powiedzieć, że w pierwszych latach XX w. na ziemiach polskich narodził się ruch społeczny - wewnętrznie zresztą zróżnicowany - na rzecz masowego uświadamiania seksualnego, po raz pierwszy na taką skalę alternatywny do kościelnego wychowania w dziedzinie seksualności człowieka ${ }^{24}$.

Już na przełomie wieków zaobserwowano też stały spadek liczby dzieci w rodzinach. Zjawisko to jest jedną z cech przypisywanych społeczeństwom modernizującym się. Można wskazać przynajmniej kilka czynników mających wpływ na zmniejszanie dzietności: rozwój higieny i medycyny, poprawa warunków życia przejawiająca się między innymi zanikiem plagi głodu, co skutkowało wzrostem szans na przeżycie. Nowe standardy higieniczne i skuteczniejsze terapie medyczne

${ }^{22}$ Np. E. Key, Stulecie dziecka, Warszawa 1904, s.87.

${ }_{23}$ J. Ś witalsk a, Kobieta nowoczesna we wszystkich okresach jej życia, Warszawa 1927, s. 143.

${ }^{24}$ J. Sikorska-Kulesza, „Skąd się wziąt twój braciszek?” Początki dyskusji o wychowaniu seksualnym dzieci i młodzieży na ziemiach polskich [w:] Kobieta i malżeństwo ..., s. 27. 
przyczyniały się do poprawy opieki nad niemowlętami i małymi dziećmi. Co prawda jeszcze w II Rzeczypospolitej wskaźnik śmiertelności niemowląt do ukończenia pierwszego roku wciąż należał do najwyższych w Europie, ale i tu zaznaczał się postęp. Był on widoczny przede wszystkim w tzw. warstwach oświeconych, które najszybciej reagowały na wskazania lekarzy i higienistów. Mając możliwości finansowe, ich przedstawiciele korzystali z wielu udogodnień. I tak coraz więcej kobiet decydowało się na pozostawanie pod opieką lekarza w okresie ciąży, a potem na poród w warunkach szpitalnych, które jak zapewniano, były bardziej higieniczne. Niemowlęta na ogół miały swoje własne łóżeczka, a nawet pokoje, oczywiście higienicznie urządzone: linoleum na podłodze, ściany pomalowane farbą olejną, podobnie jak meble. Pokoje codziennie sprzątano i wietrzono, a do dzieci zbliżano się w maseczkach. Dzieci były codziennie obmywane i wyprowadzane na spacer w specjalnie przystosowanych wózkach. Matki coraz częściej decydowały się też na karmienie piersią, stwierdzono bowiem, i to już przed wojną, że karmienie niemowlęcia mlekiem matki zapewnia mu lepszą odporność. Gdy matka z jakiegoś powodu nie mogła stosować karmienia naturalnego, miała szansę otrzymać zbilansowane mieszanki mleczne, które podawano w butelkach z gumowymi smoczkami - obowiązkowo wyparzanymi. Coraz rzadziej korzystano więc z usług mamki, a w okresie międzywojennym było to sporadyczne. Karmienie odbywało się w ściśle określonych porach. Dzieci pozostawały pod stałą opieką pediatry. W dwudziestoleciu międzywojennym wprowadzono też (idąc za przykładem niemieckiego okupanta) obowiązkowe szczepienia przeciwko ospie. Do tej pory były one zalecane przez lekarzy higienistów, ale nie wszyscy chcieli z nich korzystać. Postulowano zapewnienie dzieciom jak największej ilości ruchu. Bardzo popularna była gimnastyka, nazywana także rytmiką, oraz sporty na świeżym powietrzu: jazda na rowerze, narciarstwo, łyżwiarstwo czy jazda na sankach. Wszystkie te zalecenia zwiększały szanse na przeżycie. Skoro malała śmiertelność dzieci, wzrastały też siłą rzeczy nakłady na ich utrzymanie i wychowanie. Szanse doprowadzenia dziecka do pełnoletności powodowały, że można było mieć mniej dzieci, którym poświęcano, przynajmniej teoretycznie, więcej uwagi.

Wzrost szans na przeżycie potomstwa, większe inwestycje materialne, ale i emocjonalne, które się z tym wiązały, a także wzrost indywidualnych aspiracji postawiły w centrum zainteresowania sprawy związane z planowaniem rodziny. W dwudziestoleciu międzywojennym kompleks zagadnień związanych z kontrolowaniem płodności i opieką nad niemowlęciem nazywano świadomym macierzyństwem. Przełomem stała się niewątpliwie medykalizacja dyskursu o seksualności. Kwestie związane z rozmnażaniem stały się przedmiotem namysłu lekarzy i zostały powiązane ze zdrowiem matki i dziecka. Podkreślić należy, że wielu lekarzy dostrzegało konieczność współponoszenia odpowiedzialności za nowo narodzone dzieci również przez ojców. Postulowano więc między innymi reformę prawa i umożliwienie dochodzenia ojcostwa. Takie postulaty pojawiły się również w debacie o karalności aborcji, która toczyła się na przełomie lat 20. i 30. Zachęcano do wspólnego decydowania o rodzicielstwie. Jednak ankieta rozesłana do lekarzy przez IGS na początku lat 30. dowiodła, że nawet w tym, wydawałoby się, najbardziej świadomym środowisku najczęściej stosowaną metodą antykoncepcji były stosunek przerywany oraz aborcja. 
Zresztą właśnie powszechność aborcji - nielegalnej i karalnej - też stanowiła czynnik wpływający na wysiłki na rzecz rozpropagowania różnych metod antykoncepcji. Przełomem było tu niewątpliwie pojawienie się metody Ogina i Knausa, czyli tzw. kalendarzyka małżeńskiego, jako że została ona uznana przez Kościół katolicki (co prawda jako metoda pomagająca małżonkom niemogącym doczekać się potomstwa). Idee zachęcające do podejmowania wysiłków zmierzających do ograniczenia liczby dzieci w rodzinach i do staranniejszej opieki nad nimi dotarly na ziemie polskie ze Stanów Zjednoczonych Ameryki ${ }^{25}$. Do rozreklamowania tych postulatów przyczyniali się również eugenicy, mający na uwadze przede wszystkim „poprawienie” społeczeństwa. Adekwatnie do zdobyczy ówczesnej nauki przyjmowali oni, że po pierwsze, tylko osoby zdrowe powinny mieć dzieci, po drugie, że w skrajnych przypadkach należy pozbawiać możliwości rozmnażania ${ }^{26}$. Bardzo ważnym elementem działania społecznego eugeników było nakłanianie do świadomego macierzyństwa. Do akcji tej, połączonej zresztą wkrótce $\mathrm{z}$ walką o zniesienie paragrafów dotyczących karania za aborcję, przystąpiły i inne kręgi społeczników. Szczególnie znaną postacią kojarzoną z tymi kampaniami społecznymi był Tadeusz Boy-Żeleński, autor serii artykułów dotyczących sytuacji kobiet, wydawanych następnie w tomach Piekło kobiet i Dziewice konsystorskie. Podkreślano rujnujący wpływ wielokrotnych porodów zwłaszcza na niedożywione organizmy matek. Celem akcji było przekonanie opinii publicznej o pożytkach płynących ze świadomego rodzicielstwa zarówno dla dzieci, jak i dla rodziców. Wskazywano, że jeżeli dzieci jest mniej, rodzice mają więcej czasu, aby się nimi zajmować, i więcej pieniędzy, aby zapewnić im lepsze warunki rozwoju. W konsekwencji dzieci miały być zdrowsze i silniejsze. Zmienił się model wychowawczy. W dziecku dostrzeżono odrębną istotę, która ma swoje potrzeby, zainteresowania. Dostrzeżono wartość i specyfikę dzieciństwa jako odrębnego okresu w życiu, zaczęto też ten okres badać, dostrzegając potrzeby dziecka, wyróżniając fazy jego rozwoju. Rolą rodziców miało być wychowywanie zgodne z ustaleniami pedagogiki. Stopniowo i pozycja dziecka w rodzinie zaczęła się zmieniać. Stawało się ono w coraz większym stopniu odrębną i istotną jednostką. Okres edukacji się wydłużał, a to powodowało nie tylko lepsze przygotowanie do dorosłości, ale również wydłużenie zależności od rodziców.

${ }^{25}$ Więcej o przenikaniu modernizacyjnych projektów na ziemie polskie patrz: S. Kuźma- Markow ska, Dziecko, rodzina, płeć w amerykańskich inicjatywach humanitarnych i filantropijnych w II Rzeczypospolitej, Warszawa 2018.

${ }^{26} \mathrm{~W}$ państwie polskim eugenika znalazła również swoich zwolenników. Jeszcze przed odzyskaniem niepodległości powstało w Warszawie Towarzystwo Walki z Chorobami Wenerycznymi, przemianowane w 1922 r. na Polskie Towarzystwo Eugeniczne na czele z Leonem Wernicem. Do zwolenników rozwiązań eugenicznych należała np. Justyna Budzińska-Tylicka, założycielka pierwszej w Polsce Poradni Świadomego Macierzyństwa w 1931 r. Członkowie Towarzystwa przygotowali projekt ustaw eugenicznych, w którym znalazły się m.in. paragrafy dotyczące sterylizacji. Nie wyszły one jednak nigdy poza sferę projektowania. W innych krajach europejskich tego typu rozwiązania również cieszyły się zainteresowaniem, a nawet były realizowane (np. w krajach skandynawskich, w Szwecji do 1945 r. wysterylizowano ponad 8000 osób, głównie kobiet). W najbardziej wynaturzonej formie zrealizowano je w hitlerowskich Niemczech. 
Takie podejście do dzieciństwa było pewnym stanem idealnym, w praktyce jednak, zwłaszcza innych warstw społecznych niż inteligencja czy ziemiaństwo, sytuacja tak nie wyglądała. W rodzinach robotniczych na dzieci wciąż zwracano mało uwagi, jeśli się troszczono, to głównie o ich biologiczne przeżycie. Gdy matki pracowały, zwłaszcza małe dzieci stanowiły kłopot. Zostawiano je najczęściej pod opieką starszego, tj. np. 5-letniego rodzeństwa, czasem opiekowała się nimi babka bądź niepracująca sąsiadka. Do luksusów można było zaliczyć możliwość pozostawienia dziecka w żłobku przyfabrycznym. Co prawda ustawa o ochronie pracy młodocianych i kobiet z 1924 roku nakładała na pracodawców obowiązek otwierania żłobków, ale dotyczyło to zakładów zatrudniających ponad 100 robotników i w praktyce niemal wyłącznie państwowych. Inspekcja pracy dokonywała regularnych kontroli, sytuacja więc się poprawiała. Gdy opieki nie udało się zagwarantować, dziecko po prostu zamykano w domu, klucz pozostawiając niepracującej sąsiadce, która od czasu do czasu sprawdzała, co się z nim dzieje, przywiązywano dzieci za nogę do łóżka czy stołu, wreszcie zostawiano je w lecie na podwórku i zamykano dom na klucz ${ }^{27}$. Jednak pomimo trudnych warunków bytowania również w warstwach tzw. ludowych poprawiła się dbałość o higienę dzieci. Badania dla Łodzi wskazują, że niemowlęta kąpano codziennie. Starsze dzieci i rodzice kąpali się raz w tygodniu, raz w tygodniu też najczęściej prano. Gorzej chyba jednak było na wsi, choć ustalenia z lat międzywojennych pokazują duże zróżnicowanie w zależności od regionu. Najgorzej sytuacja wyglądała na wschodnich krańcach II Rzeczypospolitej. Lekarz relacjonujący w piśmie „Zdrowie” stan higieny na tym obszarze w 1933 roku pisał:

Nie można było przekonać tych ludzi [...], że nie wolno dawać niemowlęciu brudnego, nieprzegotowanego mleka, trzymanego w brudnym naczyniu. Mało tego wbrew moim zakazom zabobonna znachorka mleko to wlewała dziecku do ust przez brudny, przedziurawiony rożek kozi, który miał zastępować higieniczny smoczek ${ }^{28}$.

Sprawą, która wciąż nie została według mnie wystarczająco zbadana, jest kwestia relacji między rodziną a instytucjami państwowymi i prywatnymi, które działały na rzecz odciążenia jej od niektórych obowiązków. Najbardziej znacząca wydaje się tu rola szkoły, przede wszystkim obowiązkowej szkoły powszechnej, jako miejsca socjalizacji. Szkoła, stawiając sobie za cel nie tylko edukowanie, ale i wychowanie uczniów, wkraczała w kompetencje rodziców, nie zawsze zresztą mając podobne do nich zdanie na temat metod wychowawczych. W ten sposób wkraczała do życia rodzinnego i do rodzinnych relacji. O takim jej wpływie na dzieci wiejskie pisał Włodzimierz Mędrzecki ${ }^{29}$. Dobrze też ilustruje to zjawisko opis wywiadówki w szkole powszechnej zamieszczony w bardzo popularnym w ostatnich latach II Rzeczypospolitej słuchowisku autorstwa Marii Kuncewiczowej Dni powszednie państwa Kowalskich, w którym nauczyciel relacjonuje swoje rozterki dotyczące konfrontacji jego pedagogicznych metod wychowawczych z realiami spotykanymi w życiu rodzinnym jego

${ }^{27}$ Badania dla Łodzi w drugiej poł. lat 30. XX w. T. Nowackiego.

${ }_{28}$ Z. Kło sow sk i, Oplakany stan polożnictwa na wsi kresowej, „Zdrowie” 1933, nr 1-2, s. 69.

${ }^{29}$ W. Mędrzecki, op. cit., s. 158 i n. 
uczniów, w których nierzadko obecna była przemoc ${ }^{30}$. W konsekwencji, jak piszą badacze, co prawda francuskich realiów, ale i w II Rzeczpospolitej proces ten staje się widoczny w latach międzywojennych - uspołecznienie procesu kształcenia dzieci prowadzi do tego, że „Rodzina powoli przestaje być instytucją, przeradzając się jedynie w obszar stykania się życia prywatnego każdego z jej członków"31.

Nie mniej istotny dla ewoluowania relacji w rodzinie wydaje się też wpływ organizacji młodzieżowych, w tym przede wszystkim bardzo popularnego, zwłaszcza w latach międzywojennych, harcerstwa ${ }^{32}$. Stwarzało ono przestrzeń do spędzania czasu wolnego przez dzieci i młodzież bez kontroli rodziców, w swoim własnym gronie. Jak pisał w 1936 roku jeden z druhów: „rozwijało w nas religijność i patriotyzm, pomagało wyrabiać w sobie uczciwość, brak zakłamania, prostotę i potrzebę stałej pracy nad sobą; budowało twórczy stosunek do życia nie tylko w rzeczach ważnych, ale i w sprawach codziennych; pogłębiało i zacieśniało kontakt z przyrodą; wyrabiało tężyznę duchową i fizyczną"33. W przypadku dziewcząt zachęta do rozwijania samodzielności i niezależności przez długi czas stanowiła przeszkodę w akceptacji skautingu żeńskiego przez ogół ${ }^{34}$.

\section{ŻYCIE PRYWATNE - INDYWIDUALIZACJA I AUTONOMIZACJA JEDNOSTKI}

Istotne dla życia rodzinnego były też kwestie związane z indywidualizacją i autonomizacją jednostki. To właśnie w pierwszej połowie wieku, a zwłaszcza w okresie międzywojennym procesy te nabrały przyspieszenia. Życie prywatne, rozumiane przez Gerarda Vincenta jako „decyzja o charakterze indywidualnym wyznaczenia granicy między bytem osobistym i otoczeniem społecznym”, zmieniało się. Przyśpieszenie zmiany można wiązać ze skutkami Wielkiej Wojny, która z jednej strony zakwestionowała tradycyjne role kobiet i mężczyzn, z drugiej zmieniła stosunek do życia jako takiego. Wraz z rozwijającymi się trendami wychowawczymi, o których była mowa, i postępującą edukacją stanowiły konglomerat czynników powodujących zmianę relacji również wewnątrz rodziny. Trend doceniania indywidualności jednostki prowadził do rozwoju zakresu jej autonomii, również w rodzinie. To z kolei wpływało na zmianę myślenia o przestrzeni mieszkalnej. Coraz powszechniej

30 M. Kuncewiczowa, Dni powszednie państwa Kowalskich, Warszawa 1938, s. 24-30.

31 Historia życia prywatnego, t. V: Od I wojny światowej do naszych czasów, red. A. Prost, G. Vincent, Wrocław 2000, s. 91.

32 Stan ZHP na koniec 1938 r. wynosił 206182 harcerzy, harcerek, instruktorów i instruktorek.

33 Jakie wartości dało nam harcerstwo (szkic referatu hm Józefa Jakubowskiego na zjeździe wychowanków Warszawskiej Drużyny Harcerzy w dniu 13 grudnia 1936 roku), „Znak” 1980, nr 8-9, s. 1066 .

34 I. Ko zimala, Przeciwko stereotypom - sylwetka instruktorki harcerskiej na Kresach Potudniowo-Wschodnich Rzeczypospolitej [w:] Aktywność publiczna kobiet na ziemiach polskich. Wybrane zagadnienia, red. T. Pudło cki, K. Siera k ow s ka, Warszawa 2013, s. 128. 
spotykanym standardem, przynajmniej w miastach, stały się osobne łóżka dla każdego z członków rodziny. Trudniej było zapewnić osobny pokój. Wiązało się to nie tylko z możliwościami finansowymi rodzin, ale również z tym, że było stosunkowo mało dostępnych mieszkań więcej niż dwuizbowych. Jednak nawet przy tak ograniczonych możliwościach postulowano wydzielanie odrębnych przestrzeni. Dobrze to widać na przykład w projektach mieszkań budowanych w ramach WSM. Starano się wydzielać przestrzeń przeznaczoną do mycia, projektowano funkcjonalne kuchnie, które dawałyby szanse gospodyni uczestniczenia w życiu rodzinnym, oszczędzałyby jej czas. Zachęcano też do wydzielania przestrzeni odrębnej dla członków rodziny poprzez używanie parawanów, dzielenie pokojów za pomocą mebli na odrębne kąciki itd. Wzrastało poszanowanie prywatności nie tylko ojca, ale również matki i dzieci, co przyczyniało się do wyrównywania pozycji członków rodziny i do demokratyzacji ich wzajemnych relacji.

\section{PODSUMOWANIE}

Wypada zgodzić się z tezą francuskich autorów publikacji Historia życia prywatnego, którzy piszą o zachodzącym w pierwszej połowie XX wieku procesie dezinstytucjonalizacji rodziny i podkreślają, że istotną zmianą, która nastąpiła w pierwszej połowie XX wieku, było to, że wewnątrz życia prywatnego rodziny toczy się indywidualne życie prywatne. Wiek XX jest niewątpliwie okresem poszerzania granic prywatności ${ }^{35}$. Także wtedy zmieniła się definicja rodziny, zmniejszyła się liczba dzieci, które coraz częściej rodziły się w wyniku świadomej decyzji rodziców. Przełomem w tych decyzjach stało się jednak wynalezienie pigułki antykoncepcyjnej w latach 60. XX wieku. Znacznym przemianom uległ stosunek do potomstwa, które stawało się stopniowo centrum rodziny i jej wysiłków. Zmieniły się wzajemne relacje pomiędzy małżonkami, rodzicami i dziećmi. Wciąż jednak niewiele wiemy o mechanizmach podejmowania decyzji, uczuciach i mentalności członków rodziny. Należałoby zatem postulować podjęcie badań nad tymi kwestiami z wykorzystaniem narzędzi psychoanalizy, analizy autobiografii i innego rodzaju memuarystyki. Trudno jednoznacznie ocenić przemiany zachodzące w rodzinach, będące przedmiotem tego artykułu. Pokazują one duże zróżnicowanie modeli, tempa zmian i ich zakresu uzależnione od środowiska społecznego, płci, indywidualnych cech jednostek itd. Odpowiedź na tytułowe pytanie „ewolucja czy rewolucja?” nie może być zatem jednoznaczna.

${ }^{35}$ Historia życia prywatnego, t. V: Od I wojny światowej do naszych czasów..., s. 9. 


\title{
BIBLIOGRAFIA
}

\author{
Źródła
}

Jakie wartości dało nam harcerstwo (szkic referatu hm Józefa Jakubowskiego na zjeździe wychowanków Warszawskiej Drużyny Harcerzy w dniu 13 grudnia 1936 roku), „Znak” 1980, nr 8-9.

Karski M.S., Pamiętniki, oprac. nauk. i edycja J. Greloff, Warszawa 2017.

Kło s ow ski Z., Opłakany stan położnictwa na wsi kresowej, „Zdrowie” 1933, nr 1-2.

Kuncewic zow a M., Dni powszednie państwa Kowalskich, Warszawa 1938.

Oderfeldówna A., Młodzież przedmieścia. Z badań ankietowych na Ochocie, Warszawa 1937.

Pamiętniki chłopów, Warszawa 1935.

Sapieżyna z Windisch-Graetzów M., My i nasze siedliska, Kraków 2003.

Ś witalska J., Kobieta nowoczesna we wszystkich okresach jej życia, Warszawa 1927.

\section{Opracowania}

Grzeszne wiersze o matce. Pożegnanie z Jidysze Mame? [w:] Pożegnanie z Matka Polką? Dyskursy, praktyki i prezentacje macierzyństwa we współczesnej Polsce, red. R.E. Hry ciuk, E. Korolczuk, Warszawa 2012.

Historia życia prywatnego, t. V: Od I wojny światowej do naszych czasów, red. A. Prost, G. Vincent, red. nauk. przekładu t. V, T. Kulak, Wrocław 2000.

Cała A., Ostatnie pokolenie. Autobiografie polskiej młodzieży żydowskiej okresu międzywojennego ze zbiorów YIVO Institute for Jewish Research w Nowym Jorku, Warszawa 2003.

Landau-Czajka A., Przygotowanie do matzeństwa wedlug wybranych poradników z XIX i XX wieku [w:] Kobieta i matżeństwo: społeczno-kulturowe aspekty seksualności: wiek $X I X i X X$, red. A. Żarnows ka, A. Szw arc, Warszawa 2004.

Landau-Czajka A., ,,Syn będzie Lech”. Asymilacja Żydów w Polsce międzywojennej, Warszawa 2006.

Kopczyńska-J aw orska B., Łódź i inne miasta, Łódź 1999.

Key E., Stulecie dziecka, Warszawa 1904.

Kowalska-Glikman S., Drobnomieszczaństwo w XIX-wiecznej Warszawie, Warszawa 1987.

Kozimala I., Przeciwko stereotypom - sylwetka instruktorki harcerskiej na Kresach Potudniowo-Wschodnich Rzeczypospolitej [w:] Aktywność publiczna kobiet na ziemiach polskich. Wybrane zagadnienia, red. T. Pudło ck i, K. S i erak ow s ka, Warszawa 2013.

Kuźma-Markows ka S., Dziecko, rodzina, pleć $w$ amerykańskich inicjatywach humanitarnych i filantropijnych w II Rzeczypospolitej, Warszawa 2018.

Kwestie drażliwe w oświetleniu etycznym, cz.VI: Kilka słów o wspótczesnej etyce matżeńskiej, ,Kosmetyka” 1908, nr 17.

Leskiewiczowa J., Warszawa i jej inteligencja po powstaniu styczniowym 1864-1870, Warszawa 1961.

Materiaty do etnografii miasta, cz. 1, red. A. S ta w ar z, Żyrardów 1992.

Mędrzecki W., Młodzież wiejska na ziemiach Polski centralnej 1864-1939: procesy socjalizacji, Warszawa 2002.

Ogórek B., „Należy przestać spluwać dzieci na prawo i lewo”. Transformacja płodności w populacji Drugiej Rzeczypospolitej [w:] Społeczeństwo międzywojenne - nowe 
spojrzenie, red. W. Mędrzecki, J. Żarnowski, Metamorfozy Społeczne, t. 10, Warszawa 2015, s. 81-111.

O gó re k B., Niezatarte piętno? Wpływ I wojny światowej na ludność miasta Krakowa, Kraków 2018.

Rodzina - prywatność - intymność: dzieje rodziny polskiej w kontekście europejskim: zbiór studiów, red. D. Kałwa, A. Walas zek, A. Żarnow ska, Warszawa 2005.

Rüther s M., Tewjes Töchter. Lebensentwürfe ostjüdischer Frauen im 19.Jahrhundert, Köln 1996.

Si ennicka M., Rodzina burżuazji warszawskiej i jej obyczaj: druga połowa XIX i początek XX wieku, Warszawa 1998.

Sierakowska K., Rodzice, dzieci, dziadkowie... Wielkomiejska rodzina inteligencka w Polsce w latach 1918-1939, Warszawa 2002.

Sierakowska K., Rodzina robotnicza $w$ Królestwie Polskim $w$ drugiej połowie XIX i pierwszej XX wieku. Ujęcie kulturowe [w:] Rodzina, gospodarstwo domowe i pokrewieństwo na ziemiach polskich $w$ perspektywie historycznej-ciagłość czy zmiana?, red. C. Kuklo, Warszawa 2012.

Sikorska-Kowalska M., Wizerunek kobiety łódzkiej przełomu XIX $i$ XX wieku, Łódź 2001.

Sikorska-Kulesza M., „Skąd się wziąt twój braciszek?” Początki dyskusji o wychowaniu seksualnym dzieci i młodzieży na ziemiach polskich [w:] Kobieta i matżeństwo. Społeczno-kulturowe aspekty seksualności. Wiek XIX $i X X$, zbiór studiów pod red. A. Żarnowskiej, A. Szw arca, t. VIII, Warszawa 2004.

Społeczeństwo polskie XVIII i XIX wieku, t. 9, Studia o rodzinie, red. J. Le s ki ew i c zow a, Warszawa 1991.

S taw ar z A., Życie codzienne w dawnym Żyrardowie 1830-1880, Żyrardów 1983.

Szwarc A., Rygorystyczne normy i swobodne obyczaje. Matżństwo i związi pozamatżeńskie w opiniach ziemiańsko-arystokratycznej elity w połowie XIX wieku [w:] Kobieta i małżeństwo. Społeczno-kulturowe aspekty seksualności. Wiek XIX i XX, zbiór studiów pod red. A. Żarnowski ej, A. Szwarc a, t. VIII, Warszawa 2004.

Tradycyjna kultura robotnicza Żyrardowa, red. A. Woźniak, Warszawa 1982.

W nęk K., Przemiany demograficzne we Lwowie w latach 1829-1938, „Zeszyty Naukowe Uniwersytetu Jagiellońskiego. Prace Historyczne” 2008, z. 135, s. 113-127.

Wybrane problemy etnologii miasta, red. nauk. B. K o p c zy ń s k a-J a w or s k a, Łódź 1993.

Zyblikiewicz L., Dziecko w rodzinie krakowskiej w drugiej połowie XIX wieku: studium demograficzne, ,Zeszyty Naukowe Uniwersytetu Jagiellońskiego. Prace Historyczne” 2008, z. 135, s. 129-147.

Zyblikiewicz L., Kobieta w Krakowie w 1880 r. w świetle ankiet powszechnego spisu ludności. Studium demograficzne, Kraków 1999.

Ża rnow ska A., Modele rodziny i pozycja w niej kobiety w uprzemysławiajacym się mieście na przełomie XIX i XX wieku. Tradycja i modernizacja [w:] A. Żarnow ska, Kobieta $i$ rodzina $w$ przestrzeni wielkomiejskiej na ziemiach polskich $w$ XIX $i$ XX wieku, red.

A. Janiak-Jasińska, K. Si erakowska, A. Szwarc, Warszawa 2013.

Żarnowska A., Robotnicy Warszawy na przełomie XIX $i$ XX wieku, Warszawa 1995.

Żarnowska A., A. Szwarc, Przedmowa [w:] Kobieta i matzeństwo. Spoleczno-kulturowe aspekty seksualności. Wiek XIX $i$ XX, zbiór studiów pod red. A. Żarnowskiej, A. S zw a r c a, t. VIII, Warszawa 2004.

Żarnows ki J., O inteligencji polskiej lat międzywojennych, Warszawa 1965.

Żarnows ki J., Społeczeństwo Drugiej Rzeczypospolitej: 1918-1939, Warszawa 1973.

Żu raw i ck J., Inteligencja warszawska w końcu XIX wieku, Warszawa 1978. 